\title{
E-LEARNING IN ONLINE EDUCATION GAME FOR KIDS
}

\author{
Nia Karniawati ${ }^{*}$, Govena Mutia Rani ${ }^{2}$ \\ ${ }^{1}$ Departemen Ilmu Pemerintahan, Universitas Komputer Indonesia, Indonesia. \\ ${ }^{2}$ Departemen Ilmu Komunikasi, Universitas Komputer Indonesia, Indonesia \\ ${ }^{*}$ Corresponding Author: *nia.karniawati@email.unikom.ac.id
}

\begin{abstract}
This study aims to identify e-learning as a branding of kids educational online games. Descriptive method was used to present a complete overview regarding the situation related to variables examined. The results of this research are to recognize the development of branding and the benefit provided by e-learning in the application of educational games for kids. Discussing the product branding of e-learning games for kids was conducted in this research. The results of this study prove the development of technology that provides a positive side for the main community in the field of education for children and business. Therefore, branding on e-learning products in children's educational games is needed to achieve the goal of customer satisfaction and valuable consumer trust. using e-learning branding gives an image that is in the subconscious, built through information and expectations that are expected through the product
\end{abstract}

Keywords: Education, Games, E-learning.

JTIP@Attribution-ShareAlike 4.0 International License

\section{INTRODUCTION}

The impact of the development of telecommunication progress in education and training fields is unavoidable. Previous developments in Information and Communication Technology (ICT) are closely related to the existence of a number from significant changes such as those in the economy and society nowadays. This has led to increased demand in the field of education and training as an action to face the challenges of "economy knowledge" and the latest is "public knowledge" [1]. People who are aware of technological developments and digitally educated can learn and be responsible as well as productive despite the development of the education field [2]. Elearning is a learning method a part of electronic media in the education field nowadays. E-learning utilizes developments in Information and Communication Technology field. Correspondence education or distance education is where e-learning presents to be operated. There are several types of media in e-learning such as the availability of features in the form of audio, video, writing, and images [3]. E-learning has become a part of an important means to obtain education or science with the help of advances in information and communication technology, namely electronic media, especially on the Internet [4].

The presence of educational games and their use in learning environments is being a trend nowadays. Game-based education has motivational and immersive characteristics that have been studied in depth with literary sources. However, the system model and implementation of educationbased games remain difficult to understand. In this study, we analyze several requirements relevant to the design of educational games in online education as well as general game design methods that include adaptation and assessment features are proposed. The specific implementation of the design is explained about its applications and other environments [5]. The definition of branding continues to grow from starting a brand or selling a product, a service, or a company that deals with things that are seen from brands such as trade names, logos, or other visual features. Nowadays, it also means image, credibility, character, impression, and perception for consumers [6]. Branding is a symbol of the manifestation of information that has something to do with a product or service [7]. The first things that are proposed for a brand are the brand's name, promises, logos, and packaging that shape the brand's identity. At present, branding is 
increasingly developing to support the entire development process of the brand creator, name, identity, and in some cases including brand advertising [8].

In the competitive business environment, industrial marketers must work harder to achieve some differentiation for their products so that they are not seen as commodities. Many companies have tried to achieve this differentiation by branding their products. However, branding is more than just putting the company's name on the product and broadcasting that name to its target audience. For industrial products, branding is a multidimensional construction that not only covers the way customers see physical products, but also logistics, customer support, and the image and company policies that accompany products [9]. Marketing in branding is distinguished by aspects of brand psychology with aspects of the experience. Psychological aspects, often referenced as brand images, are images that are built in the subconscious of consumers through information and expectations expected through the product. A holistic approach to building brands includes the structure of brands, businesses, and people involved in the product [10]. This study aims to recognize educational branding e-learning games for children. Descriptive method was used to present a complete overview regarding the situation related to variables examined.

Smartphone into smart tools that have many capabilities fot two-way communication, multiedia upon ability, and education. The world of education today's increasingly spohisticated, the implementation is to create a conducive learning atmosphere,interesting and creative. Technology advances can assist and facilitate in various ways, especially learning [11].

\section{METHOD}

Descriptive method was used in this research. The technique of data collecting we used is the literature method from previous research related to the branding development and e-learning in educational games for children. Therefore, it can analyze how much influence branding in e-learning technology has on educational games for children. This educational game used Growing Tree Random algorithm by choosing node randomly (See Figure 1) [12]. When the user choose a menu, it will be particularly directed according to the derivative from node (menu). Therefore, the user will get the need according to their desire.

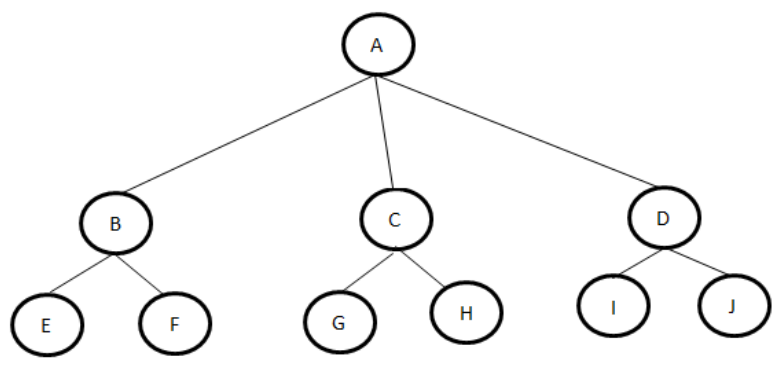

Figure 1. Growing Tree Algorithm

\section{RESULTS AND DISCUSSION}

Building a strong brand is similar to building a house. To obtain a sturdy house building, it requires a strong foundation. Likewise, building and developing brands also requires a strong foundation. There are ways to build a brand, in this case, is to do branding, namely:

\section{Positioning}

Positioning the right brand in various ways, such as placing the position of a product in detail and more specifically for the customers. Building and developing positioning is putting all aspects of brand value as a part of the functional benefits that are consistently applied. The purpose is to make brands always become number one in the minds of consumers, especially customers. In this study, the position created is the position on the perceptions of consumers where products are for children, with brand value as an educational tool packed in elearning games by getting to know Indonesian culture in a fun way (see Figure 2).

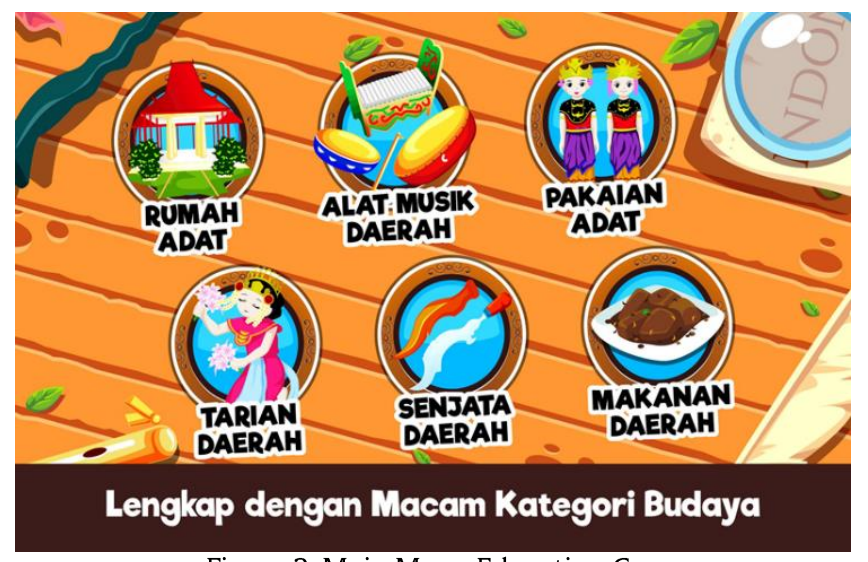

Figure 2. Main Menu Education Game

We can see from the brand positioning of the product with an interesting character according to the placement for children and the brand value presented, namely having an educational function, in this case, learning Indonesian culture (see Figure 3). 


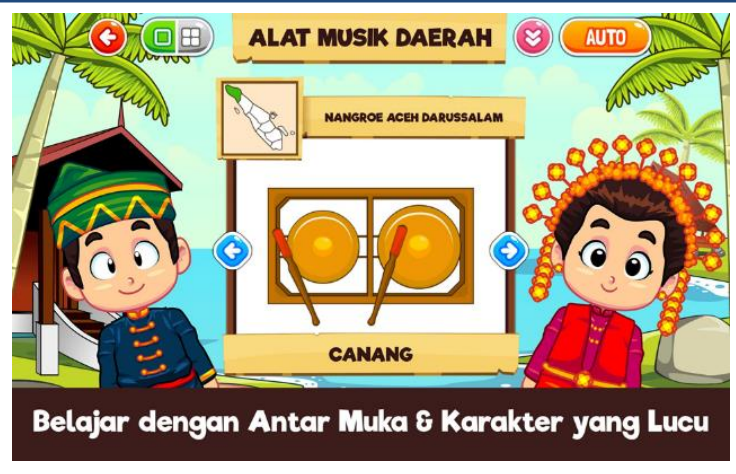

Figure 3. Educational game content.

Brand value

The brand that is more precise and successful in positioning strategies in customers' perception, these brands will increasingly have selling points that can compete in the market. To manage these things, brand value is needed. Compared to a garment, positioning is a measure of suitability for the wearer [9]. While brand value is the beauty of the colors and models in the clothing. The brand value will shape the brand's personality. This means that a brand's personality changes faster than brand positioning because it reflects the fluctuations in customer tastes.

\section{Concept}

In the final stage of the branding process that must be prepared to communicate the brand value and the right positioning to consumers, which must be supported by the existence of the right concept. The development of concepts designed for a brand is a process that requires creativity because it is different from just positioning, the concept can continually change because of its dynamic nature that conforms to the renewal of the product that the customer wants to instill. A good concept has an implementation to communicate the elements of brand value and the right positioning so that the brand image can be improved continuously (see Figure 4).

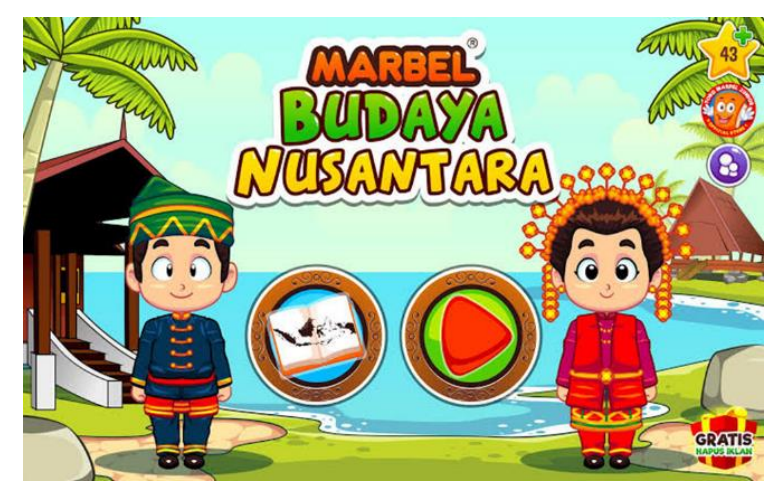

Figure 4. Cover of Education Game
With the right concept such as making an attractive appearance using a good color composition, products can be well distributed to consumers. The characters that are in line with product concepts and market objectives, attractive and easy to remember by consumers or markets, resulting in the achievement of brand value and right positioning to consumers.

\section{CONCLUSION}

The development of technology makes it easy for society, especially in the educational field for children and business[13]. Therefore, branding on an e-learning product in educational games for children is needed to achieve customer satisfaction and consumer trust in the product. With e-learning branding, the image that exists in the subconscious of consumers is built through information and expectations expected through the product.

\section{REFERENCES}

[1] El-Seoud, S., Taj-Eddin, I., Seddiek, N., Ghenghesh, P., \& El-Khouly, M. The impact of elearning on Egyptian higher education and its effect on learner's motivation: A case study. Computer Science and Information Technology, vol. 2 no. 3, pp.179-187, 2014.

[2] Andone, D., Holotescu, C., \& Grosseck, G. 2014. Learning communities in smart cities. Case studies. In 2014 International Conference on Web and Open Access to Learning (ICWOAL) (pp. 1-4). IEEE.

[3] Lahti, M., Hätönen, H., \& Välimäki, M. Impact of e-learning on nurses' and student nurses knowledge, skills, and satisfaction: a systematic review and meta-analysis. International journal of nursing studies, vol. 51 no. 1, pp.136-149, 2014.

[4] Makkar, L., Alsadoon, A., Prasad, P. W. C., \& Elchouemi, A. Impact of e-Learning on students: A proposal and evaluation of enhanced elearning model to increase the academic performance of university students. In 2016 Sixth International Conference on Digital Information Processing and Communications (ICDIPC)(pp. 87-92), IEEE, 2016.

[5] Qian, M., \& Clark, K. R. Game-based Learning and 21st century skills: A review of recent research. Computers in Human Behavior, 63, pp.50-58, 2016.

[6] Punjaisri, K., \& Wilson, A. The role of internal branding in the delivery of employee brand promise. In Advances in corporate branding, pp. 91-108. Palgrave Macmillan, London, 2017. 
[7] Soegoto, E. S., \& Utomo, A. T. Marketing Strategy Through Social Media. In IOP Conference Series: Materials Science and Engineering, vol. 662 no. 3, p. 032040. IOP Publishing, 2019.

[8] Kaasinen, E., Roto, V., Hakulinen, J., Heimonen, T., Jokinen, J. P., Karvonen, H., ... \& Tokkonen, H. Defining user experience goals to guide the design of industrial systems. Behaviour \& Information Technology, vol. 34 no. 10, pp.976991, 2015.

[9] Rahman, N. A. A., Melewar, T. C., \& Sharif, A. M. The establishment of industrial branding through dyadic logistics partnership success (LPS): The case of the Malaysian automotive and logistics industry. Industrial Marketing Management, vol. 43 no. 1, pp.67-76, 2014.

[10] Venkataraman, S. The distinctive domain of entrepreneurship research. In Seminal Ideas for the Next Twenty-Five Years of Advances pp. 520. Emerald Publishing Limited, 2019.

[11] Novaliendry, D., \& Andriani, S. English Edugame Application for Childhood base on Android. Jurnal RESTI (Rekayasa Sistem Dan Teknologi Informasi), 4(1), 187-192, 2020.

[12] Benkercha, R., \& Moulahoum, S. Fault detection and diagnosis based on C4. 5 decision tree algorithm for grid connected PV system. Solar Energy, 173, 610-634, 2018.

[13] A. Samala, B. Fajri, F. Ranuharja, and R. Darni, "PEMBELAJARAN BLENDED LEARNING BAGI GENERASI Z DI ERA 4.0", tip, vol. 13, no. 1, pp. 45-53, Mar. 2020. 